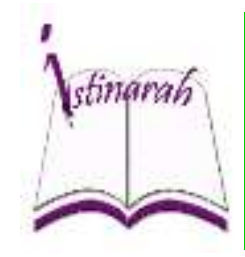

Istinarah: Riset Keagamaan, Sosial dan Budaya, Vol 1 (2), Desember 2019

ISSN : --------- (Print) ............... (Online $)$

Tersedia online di http://ecampus.iainbatusangkar.ac.id/ojs/index.php/istinarah/index

\title{
Istri Salihah dalam Perspektif Al Quran
}

\author{
Halmy Muharni *) \\ Institut Agama Islam Negeri \\ Batusangkar \\ Sumatera Barat, Indonesia \\ E-mail: \\ halmymuharni@gmail.com
}

\section{Risman Bustamam}

Institut Agama Islam Negeri

Batusangkar.

Sumatera Barat, Indonesia

E-mail:

rismanbustamam@yahoo.com

*) Corresponding Author

Kata Kunci : Istri, Salihah, al-Quran

\begin{abstract}
Abstrak: Pokok Permasalahan dalam penelitian ini adalah penafsiran ayat-ayat tentang istri salihah dalam kitab-kitab tafsir masih dalam bentuk penafsiran tahlili, sehingga pemahaman orang-orang tentang konsep istri salihah belum komprehensif, dan diperlukan adanya penafsiran dengan metode tematik (maudhu'i), supaya pemahaman tentang istri salihah bisa dipahami dengan utuh. Tujuan penelitian ini adalah untuk mengkaji, Bagaimanakah istri salihah dalam perspektif al-Quran. Metode analisis yang digunakan dalam penelitian ini adalah metode tafsir tematik atau maudhu'i. Hasil penelitian ini adalah istri salihah dalam perspektif al-Quran dapat dilihat dari dua sisi: (1) ciri istri sebagai perempuan salihah dalam perspektif al-Quran yaitu; (a) istri salihah yang menahan pandangannya (b) istri salihah yang menutup aurat, (c) istri salihah yang menjaga kehormatan diri, (d) istri salihah yang memiliki ketaatan secara utuh (kaffah) kepada Allah SWT. (2) tugas dan tanggungjawab istri terhadap suami dalam perspektif al-Quran yaitu; (a) isteri salihah yang patuh terhadap kepemimpinan suaminya, (b) istri salihah yang memelihara diri dan melaksanakan kewajibannya, (c) istri yang mampu meneladani figur-figur isteri salihah dalam al-Quran.
\end{abstract}

Abstract: The main problem in this study is the interpretation of the verses about salihah wife in the commentaries is still in the form of tahlili interpretation, so that people's understanding of the concept of salihah wife is not yet comprehensive, and interpretation is required by the thematic method (maudhu'i), so that understanding of salihah wife can be understood as a whole. The purpose of this study is to examine, How is the wife salihah in the perspective of the Quran. This research uses library research methods. The analytical method used in this study is the thematic interpretation method or maudhu'i. The results of this study are the salihah wife in the perspective of the Koran can be seen from two sides: (1) the characteristics of the wife as a salihah woman in the perspective of the Quran namely; (a) salihah wives who hold their views (b) salihah wives who cover genitalia, (c) salihah wives who maintain self-respect, (d) salihah wives who have complete obedience (kaffah) to Allah SWT. (2) the duties and responsibilities of the wife towards her husband in the perspective of the Koran namely; (a) salihah wife who obeys her husband's leadership, (b) salihah wife who takes care of herself and carries out her obligations, (c) wife who is able to emulate the figures of salihah wife in the Quran. 


\section{PENDAHULUAN}

Pernikahan merupakan satu dari sekian banyak rahmat Allah SWT yang terlimpah untuk manusia. Dengan menikah sepasang insan terbebas dari rasa gelisah. Dengan menikah, seorang insan dihalalkan untuk saling berkasih sayang sehingga hatipun menjadi tenang. Akan tetapi, bagi seorang muslim yang baik, pernikahan bukanlah ajang mencari kesenangan dan status semata, tetapi dengan menikah diharapkan dapat meraih banyak berkah. Pernikahan yang tidak hanya memberikan kesenangan di dunia, tetapi juga menambah nilai ibadah untuk kemuliaan akhirat (Mulyadi, 2010: viii).

Tujuan pernikahan akan tercapai apabila kedua calon mempelai telah siap secara lahir dan bathin. Kesiapan tersebut akan menjadi benteng yang kuat bagi rumah tangga mereka. Pada prinsipnya, ketika seseorang sedang menyiapkan diri sebagai istri idaman berarti mengusahakan diri untuk mendapat calon suami idaman. Hal ini sebagaimana janji Allah SWT dalam Q.S An Nur ayat 26 berikut:

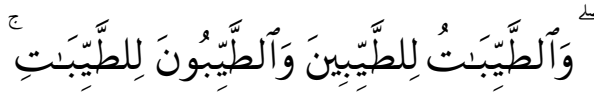

Dan wanita-wanita yang baik adalah untuk laki-laki yang baik dan laki-laki yang baik adalah untuk wanita-wanita yang baik (pula).

Penzina tidak wajar menikah kecuali lawan seksnya yang penzina pula. Hal itu disebabkan telah menjadi sunnatullah bahwa seseorang selalu cenderung kepada yang memiliki kesamaan dengannya. (Shihab, 2002: 512).

Rasulullah SAW bersabda:

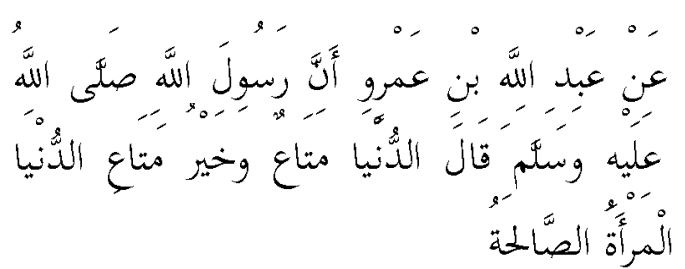

Dari Abdullah bin 'Amru bahwasannya Rasulullah shallallahu 'alaihi wasallam bersabda: "Dunia adalah perhiasan dan sebaik-baik perhiasan adalah wanita shalihah" (HR.Muslim, No-2668).

Hadits di atas menggambarkan keistimewaan dan kemuliaan yang melekat pada diri perempuan jika ia senantiasa bersifat salihah.

Dalam Islam, perempuan salihah merupakan perempuan idaman, baik bagi dirinya maupun calon suaminya. Perempuan salihah akan membuat dirinya berharga di hadapan Allah SWT, Rasul-Nya, dan sesama manusia. Sementara bagi seorang suami, istri salihah akan membuat rumah tangganya menjadi abadi dan bahagia. 
Istri salihah merupakan bekal terbaik yang hendak dipersiapkan oleh seorang perempuan setelah bertakwa kepada Allah.

Hal itu sebagaimana sabda Rasulullah SAW:

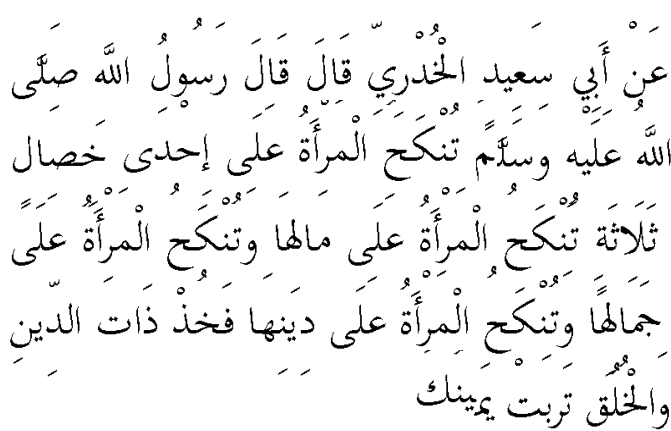

Dari Abu Sa'id Al Khudri ia berkata; Rasulullah shallallahu 'alaihi wasallam bersabda: "Wanita dinikahi karena tiga hal; dinikahi karena hartanya, dinikahi karena kecantikannya, dan dinikahi karena agamanya. Maka nikahilah atas dasar agama dan akhlak maka engkau akan beruntung." (Musnad Ahmad bin Hanbal, No 1340)

Rasulullah SAW bersabda dalam hadis riwayat Ahmad, No.1573, yang berbunyi:

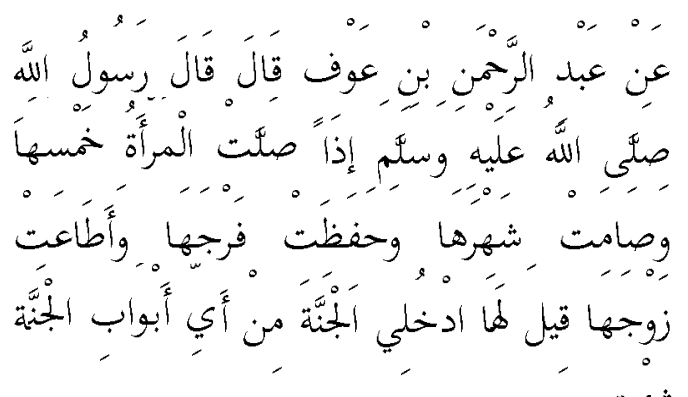

Dari Abdurrahman bin Auf berkata; Rasulullah SAW bersabda: "Apabila seorang istri melaksanakan shalat lima waktu, berpuasa di bulan Ramadhan, menjaga kemaluannya dan taat kepada suaminya, niscaya akan dikatakan kepadanya; 'Masuklah kamu ke dalam syurga dari pintu mana saja yang kamu inginkan'.

Hadist di atas menegaskan bahwa Rasulullah sangat menjunjung tinggi seorang wanita salihah yang mampu melayani hak-hak suaminya. Oleh karena itu ia mendapat ganjaran surga Allah SWT. Namun bagi seorang istri yang menentang perintah suaminya, menyakiti hati suami dengan perkataan, maupun tindakan, maka Allah juga akan membalasnya dengan hukuman yang setimpal, karena perilaku tersebut tidak patut dilakukan oleh seorang istri terhadap suaminya. Sebab, hal itu bertentangan dengan ajaran Islam.

Menjadi seorang istri yang salihah seharusnya mampu mempertahankan mahligai rumah tangganya dengan baik, ia akan turut serta membantu suami dalam mencukupi kebutuhan keluarga, melengkapi kekurangan suami, senantiasa merasa puas dengan pemberian suami, dan senantiasa setia dalam suka maupun duka. Namun fakta hari ini, masih banyak para calon istri yang belum mengetahui tentang hal tersebut. Minimnya pengetahuan tentang tugas dan fungsi sebagai istri salihah menyebabkan banyak terjadi 
perselisihan antara suami dan istri dalam rumah tangga bahkan tidak sedikit pula mahligai rumah tangga kandas dan berakhir dengan perceraian.

Dalam al-Quran Allah SWT telah memberikan gambaran serta ganjaran yang diperoleh oleh seorang istri yang berkhianat terhadap suami (istri yang tidak taat perintah suami) sebagaimana yang terdapat dalam Q.S At Tahrim ayat 10 :

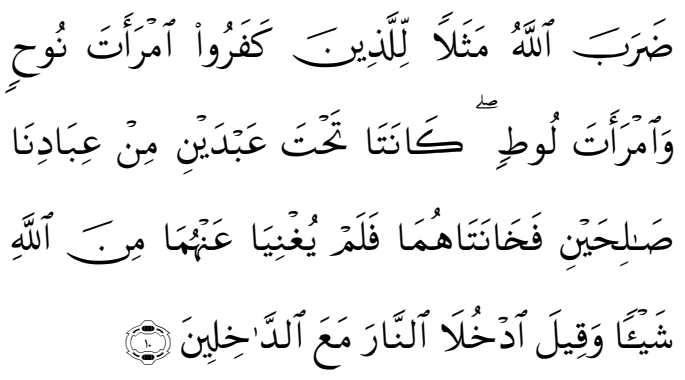

Artinya, Allah membuat istri Nuh dan istri Luth sebagai perumpamaan bagi orang-orang kafir. keduanya berada di bawah pengawasan dua orang hamba yang saleh di antara hamba-hamba kami; lalu kedua istri itu berkhianat kepada suaminya (masing-masing), Maka suaminya itu tiada dapat membantu mereka sedikitpun dari (siksa) Allah; dan dikatakan (kepada keduanya): "Masuklah ke dalam Jahannam bersama orang-orang yang masuk (jahannam)".

Allah SWT membuat suatu perumpamaan, yakni perihal istri nabi Nuh as dan Nabi Luth as. Keduanya berada di bawah pengawasan dan ikatan perkawinan dua orang hamba yang saleh di antara hamba-hamba
Allah SWT, tetapi keduanya menghianati suaminya, mereka tidak mendukung dan menghambat tugas kenabian suaminya. Allah memasukkan keduanya ke dalam kelompok yang dijatuhi siksa oleh Allah SWT. Suami masing-masing tidak dapat membantu mereka berdua sedikit pun untuk menghindari jatuhnya siksa (Shihab, 2012: 326).

Dalam al-Quran banyak sekali ayat-ayat yang berbicara tentang istri salihah yang bisa dijadikan sebagai pedoman untuk meniti kehidupan berumah tangga, khususnya untuk istri.

\section{METODE PENELITIAN}

Penelitian ini adalah penelitian kepustakaan (library research). Metode analisis yang digunakan dalam penelitian ini adalah metode tafsir tematik atau maudhu'i. Sedangkan untuk menganalisis penafsiran menggunakan pendekatan, tafsir, ilmu tafsir, dan hermeneutik tafsir. Sumber data primer dalam penelitian ini adalah ayat-ayat al-Quran yang berkaitan dengan istri salihah kemudian kitabkitab tafsir seperti; kitab Tafsir An-Nur karangan Muhammad Hasbi Ash Shiddieqy, Tafsir Al-Misbah karangan 
Quraish Shihab, dan Tafsir Fi Zhilalil Quran karangan Sayyid Quthb. Sedangkan sumber data sekunder adalah kamus-kamus dan buku-buku yang berkaitan dengan pokok pembahasan.

\section{HASIL DAN PEMBAHASAN}

Hasil penelitian ini adalah istri salihah dalam perspektif al-Quran yaitu istri yang beriman kepada Allah, taat, serta patuh terhadap apa yang diturunkan Allah kepada Nabi Muhammad SAW, sehingga dengan keimanan yang dimiliki oleh istri salihah akan nampak pengaruhnya secara lisan serta amalannya. Untuk mengetahui tolak ukur seorang istri salihah dalam perspektif al-Quran dapat dilihat dari dua sisi yaitu dari segi ciri-ciri dan tugas.

\section{Ciri Seorang Istri Sebagai Perempuan Salihah}

Diantara ciri seorang istri sebagai perempuan salihah dalam perspektif alQuran adalah sebagai berikut:

Pertama: Mampu menahan pandangan yaitu isteri yang mampu menahan diri dari melihat hal-hal yang tidak diperbolehkan oleh syariat.
Seperti melihat aurat laki-laki selain suaminya, sebagaimana laki-laki juga di perintahkan untuk menahan pandangannya dari melihat aurat perempuan selain isterinya (Q.S An Nur: 31).

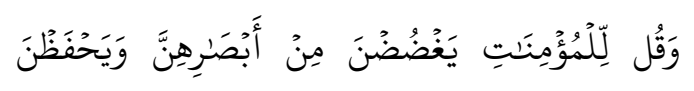

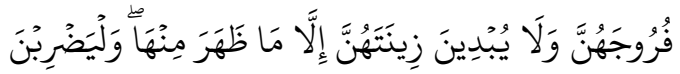

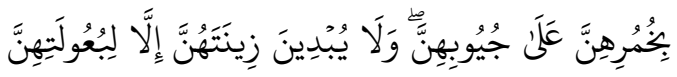

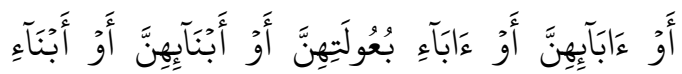

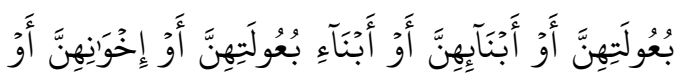

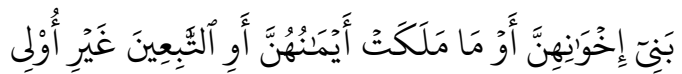

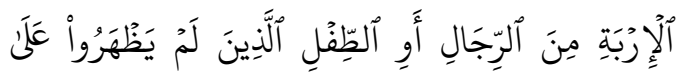

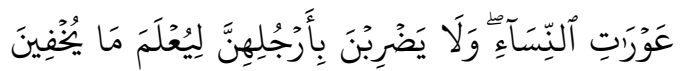

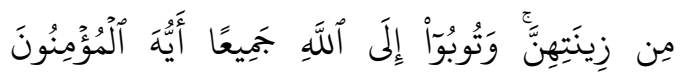
(1.) لَعَلَّكُمْ تُفْلِحُونَ

Katakanlah kepada wanita yang beriman: "Hendaklah mereka menahan pandangannya, dan kemaluannya, dan janganlah mereka Menampakkan perhiasannya, kecuali yang (biasa) nampak dari padanya. dan hendaklah mereka menutupkan kain kudung kedadanya, dan janganlah Menampakkan perhiasannya kecuali kepada suami mereka, atau ayah mereka, atau ayah suami mereka, atau putera-putera mereka, atau puteraputera suami mereka, atau saudarasaudara laki-laki mereka, atau putera- 
putera saudara lelaki mereka, atau putera-putera saudara perempuan mereka, atau wanita-wanita Islam, atau budak- budak yang mereka miliki, atau pelayan-pelayan laki-laki yang tidak mempunyai keinginan (terhadap wanita) atau anak-anak yang belum mengerti tentang aurat wanita. dan janganlah mereka memukulkan kakinyua agar diketahui perhiasan yang mereka sembunyikan. dan bertaubatlah kamu sekalian kepada Allah, Hai orang-orang yang beriman supaya kamu beruntung.

Dalam kitab Tafsir An-Nur, Hasbi

Ash Shiddieqy menjelaskan bahwa, yang dimaksud dengan menahan pandangan dan kemaluan adalah jangan perempuan melihat bagian yang terlarang dari lelaki asing yang bukan mahramnya, bagian dari antara pusat (perut) dan lutut serta bagian dari tubuh seorang perempuan. Larangan melihat itu berlaku pada bagian-bagian tubuh lawan jenis ketika dalam keadaan terbuka, dan inilah yang dimaksud dengan "Haram seorang perempuan melihat lelaki". Tidak ada seorang ulama pun yang mengatakan bahwa seorang perempuan haram melihat bagian di antara pusat dan lutut dari seorang perempuan lain dalam keadaan bagian tertutup secara sempurna. Dan hendaklah mereka menutup kemaluan atau bagian auratnya sebagaimana mereka hendak memelihara diri dari perbuatan zina (Ash Shiddieqy, 2011, Jilid 18:212).

Sedangkan yang dimaksud dengan jangan menampakkan perhiasan adalah jangan perempuan menampakkan perhiasan dirinya yang dikenakan pada bagian tubuh yang terlarang terbuka. Tegasnya, jangan mereka menampakkan bagian-bagian tubuh yang menjadi tempat perhiasan itu, seperti tempat pemakaian kalung, kecuali perhiasan yang biasa terlihat, perhiasan yang terdapat di muka dan telapak tangan (Ash Shiddieqy, 2011, Jilid 18:212).

Ibnu Abbas, sebagaimana diterangkan oleh Ash Suyuthi dalam kitab Al Iklil menetapkan bahwa yang dimaksud dengan bagian yang biasa terlihat adalah muka dan telapak tangan. Begitu juga pendapat Ibnu Umar dan Aisyah, sebagian ulama menambah dengan telapak kaki (Ash Shiddieqy, 2011, Jilid 18:213).

Penetapan Ibnu Abbas, Ibnu Umar, dan Aisyah ini menjadi dalil bagi orang yang membolehkan melihat muka (wajah) perempuan dan telapak tangannya. Jadi tidak dikhawatirkan timbulnya fitnah. Yang menjadi aurat mereka adalah bagian tubuh selain 
wajah dan telapak tangan, ditambah telapak kaki. Kata As Sayyid Rasyid, yang dimaksud dengan 'bagian yang nampak' adalah muka, telapak tangan (tangan), dan pakaian-pakaian yang lahir (terlihat) seperti baju luar (Ash Shiddieqy, 2011, Jilid 18:213).

Kandungan ayat ini memberi peringatan bahwa perempuan pada zaman pertama kelahiran Islam memperlihatkan diri di depan bukan mahramnya dalam keadaan terbuka untuk tempat pemakaian perhiasan dan pada bagian yang dapat menimbulkan nafsu. Maka, al-Quran melarang yang demikian itu, serta menyuruh mereka menutup tempat-tempat pemakaian hiasan dengan ujung kerudung. Ringkasnya, ayat ini memberi ketetapan bahwa membuka muka dan kedua tangan adalah hal yang wajar. Tidak ada sesuatu ayat atau sesuatu hadits yang memansukhkan (menghapus) hukum ini (Ash Shiddieqy, 2011, Jilid 18:213).

Seluruh ulama sependapat bahwa muka dan kedua tangan bukanlah aurat, dengan berdalil kepada ayat ini dan hadits yang mutawatir, yaitu perempuan berihram dalam keadaan terbuka muka dan kedua tangannya.
Dengan keadaan muka dan kedua tangan terbuka, perempuan boleh mengerjakan berbagai macam pekerjaan dan boleh mendatangi tempat-tempat umum (Ash Shiddieqy, 2011, Jilid 18:213).

Ulama-ulama yang mengharamkan perempuan membuka muka dan kedua tangannya seperti An Nawawi dan golongan Asy Syafi'iyah menakwilkan yang demikian itu dengan alasan takut fitnah. Fitnah adalah hal yang datang kemudian, bukan merupakan pokok persoalan dan tidak berlaku tetap. Bagaimana mungkin dapat menghindarkan diri dari melihat muka dan kedua telapak tangan perempuan yang terbuka ketika ia melaksanakan amalan-amalan haji, seperti tawaf, sa'i, dan wukuf?. Semua orang yang mendalami hukum Islam mengetahui bahwa perempuan menampakkan mukanya ketika berihram adalah wajib (Ash Shiddieqy, 2011, Jilid 18:214).

Sedangkan yang dimaksud dengan menutup kain kerudung sampai ke dada dijelaskan bahwa, apabila diperhatikan makna "Juyyub", maka dapat dimaknai dengan dada. Kalau demikian, maka yang disuruh menutup adalah dada. Menutup dada bisa dilakukan dengan 
menurunkan ujung kudungnya atau dengan memakai baju yang menutup dada. Dalam ayat ini tidak ada ketegasan perempuan harus menutup batang lehernya. Sudah nyata bahwa yang disuruh adalah menurunkan ujung kudungnya atas dada, karena perempuan-perempuan Arab zaman dahulu mengenakan baju yang bagian lehernya terbuka lebar, sehingga terlihatlah buah dadanya (payudara). Menurut lahiriah ayat ini, kerudung adalah pakaian perempuan yang biasa dipakai pada zaman jahiliyah. Nabi bersabda: "Tidak sah shalat dengan tidak memakai kerudung" memberi pengertian bawa perempuan kala itu “Ada yang memakai kerudung” (Ash Shiddieqy, 2011, Jilid 18:215).

Dan yang dimaksud dengan jangan menghentakkan kaki ketika berjalan adalah larangan perempuan menghentakkan kakinya pada waktu berjalan supaya terdengar gemerincing gelang kakinya. Sebab yang demikian itu dapat menimbulkan perhatian lelaki kepada mereka dan dapat menimbulkan prasangka bahwa perbuatan mereka memberikan suatu isyarat tertentu (Ash Shiddieqy, 2011, Jilid 18:215).

Kedua: Menutup aurat yaitu perintah kepada perempuan jika hendak keluar rumah agar menutupi tubuhnya, kepalanya, serta bagian dadanya dengan jilbab (Q.S Al Ahzab: 59).

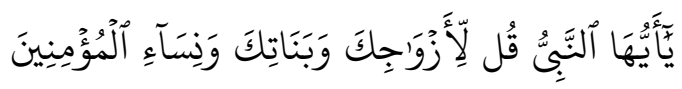

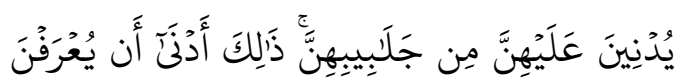

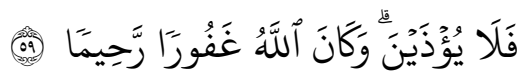

Hai Nabi, katakanlah kepada isteriisterimu, anak-anak perempuanmu dan isteri-isteri orang mukmin: "Hendaklah mereka mengulurkan jilbabnya ke seluruh tubuh mereka". Yang demikian itu supaya mereka lebih mudah untuk dikenal, karena itu mereka tidak di ganggu. Dan Allah adalah Maha Pengampun lagi Maha Penyayang

Dalam kitab Tafsir Fi Zhilalil Quran, Sayyid Quthb menjelaskan bahwa, Allah SWT memerintahkan Nabi agar menyuruh isteri-isterinya, anak-anak wanitanya, dan wanitawanita orang beriman secara umum, bila mereka keluar menunaikan kebutuhannya, agar menutupi tubuhnya, kepalanya, dan belahan baju yang terletak di dadanya, dengan jilbab yang menyelimutinya. Sehingga dengan kostum dan pakaian seperti itu, mereka kelihatan beda dan menjadikan mereka aman dari gangguan orangorang yang fasik. Karena dengan pengenalan dan ciri khas yang seperti 
itu secara bersama-sama mengesankan rasa malu dan bersalah dalam pribadi orang-orang yang biasanya sengaja mencari-cari cela untuk menghina dan menggoda wanita (Quthb, 2001, Jilid XXII:289).

Ketiga: Menjaga kehormatan diri, sebagaimana ibunda Nabi Isa AS yang menjadikan kehormatannya terletak pada kesucian, bukan pada kecantikan (Q.S At Tahrim: 12).

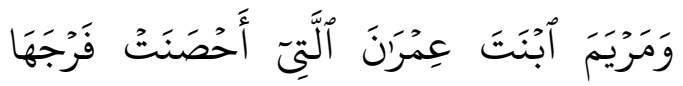

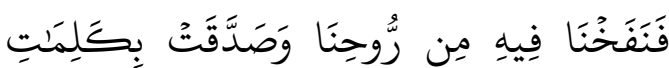

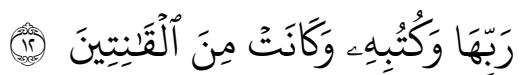

Dan (ingatlah) Maryam binti Imran yang memelihara kehormatannya, Maka Kami tiupkan ke dalam rahimnya sebagian dari ruh (ciptaan) Kami, dan Dia membenarkan kalimat Rabbnya dan Kitab-KitabNya, dan Dia adalah Termasuk orang-orang yang taat.

Dalam kitab Tafsir An-Nur, Hasbi Ash Shiddieqy menjelaskan bahwa, Allah membuat tamsilan untuk orangorang yang beriman dengan keadaan Maryam yang diberi berbagai macam kemuliaan dunia dan akhirat. Allah telah memilih Maryam, meskipun kebanyakan kaumnya terdiri dari orang-orang kafir, Maryam menolak ketika tangan Jibril hendak memegangnya, sambil menyatakan dirinya (Maryam) meminta perlindungan kepada Allah. Dengan itu Maryam membuktikan kesucian dirinya. Kemudian Jibril meniup leher baju Maryam, lalu Maryam pun hamil. Maryam membenarkan semua syariat Allah dan kitab-kitab Nya yang diturunkan kepada para Nabi dan Maryam merupakan salah seorang yang mengabdi kepada Allah, Tuhan semesta alam (Ash Shiddieqy, 2011, Jilid 28:376-377).

Keempat: Memiliki ketaatan secara utuh (kaffah) kepada Allah dengan menjalankan sepuluh sifat yaitu Islam, iman, al qunuth, ash shidqu, ash shabru, al khusyu', at tasadduq, ash shaum, hifzul fajri, dzakarallaha katsiran sebagaimana yang terdapat dalam Q.S Al Ahzab: 35:

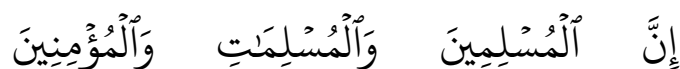

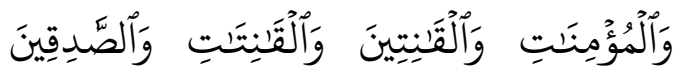

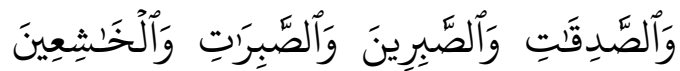

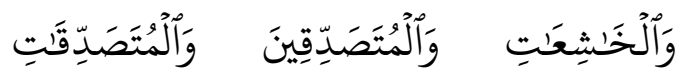

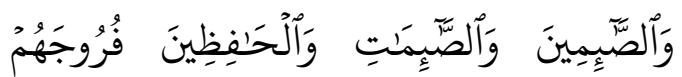

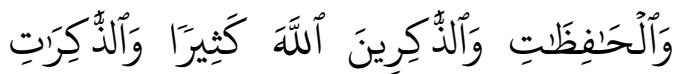

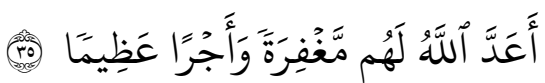
Sesungguhnya laki-laki dan perempuan yang muslim, laki-laki dan perempuan yang mukmin, laki-laki dan perempuan yang tetap dalam ketaatannya, laki-laki dan perempuan yang benar, laki-laki 
dan perempuan yang sabar, laki-laki dan perempuan yang khusyuk, laki-laki dan perempuan yang bersedekah, lakilaki dan perempuan yang berpuasa, laki-laki dan perempuan yang memelihara kehormatannya, laki-laki dan perempuan yang banyak menyebut (nama) Allah, Allah telah menyediakan untuk mereka ampunan dan pahala yang besar.

Dalam kitab Tafsir Al-Misbah, Quraish Shihab menjelaskan bahwa, berdasarkan ayat di atas, riwayatriwayat mencatat beberapa nama, seperti Ummu Salamah, Asma' binti Umais, Um 'Umarah al Anshariyah, masing-masing menemui Nabi dan menanyakan ayat tersebut. Allah berfirman : sesungguhnya laki-laki muslim dan perempuan muslimah, yakni laki-laki dan perempuan yang taat kepada Allah, laki-laki mukmin dan perempuan mukminah yang kukuh imannya, laki-laki yang taat dengan penuh hormat secara mantap dan mukhlis dan perempuan yang taat demikian pula, laki-laki yang benar dalam sikap, ucapan, dan perbuatannya, dan demikian juga perempuan yang benar, laki-laki penyabar dan perempuan penyabar, yakni sabar menghadapi cobaan, tugas, dan tanggungjawab, laki-laki yang khusyuk dan perempuan yang khusyuk, laki-laki yang gemar bersedekah, lakilaki yang sering berpuasa, perempuan yang sering berpuasa, laki-laki yang selalu memelihara kemaluannya dan perempuan yang selalu memelihara kehormatannya, laki-laki yang banyak berzikir menyebut nama Allah dan perempuan yang banyak berzikir menyebut nama Allah, Allah telah menyediakan untuk tiap-tiap orang dari mereka ampunan dan pahala yang besar (Shihab, 2002, vol 11:472).

Kelima: Beramal salih, sebagaimana terdapat dalam Surat An Nisa': 124:

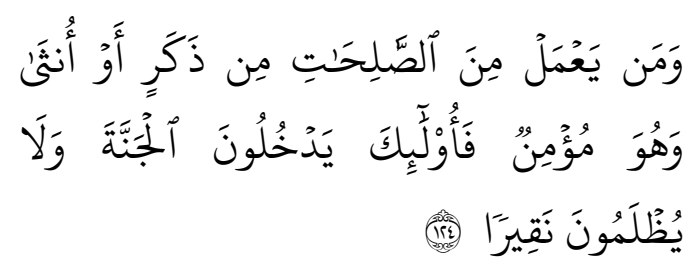

Barangsiapa yang mengerjakan amalamal saleh, baik laki-laki maupun wanita sedang ia orang yang beriman, Maka mereka itu masuk ke dalam surga dan mereka tidak dianiaya walau sedikitpun.

Dalam kitab Tafsir Fi Zhilalil Quran, Sayyid Quthb menjelaskan bahwa, ayat ini merupakan nash yang jelas yang menunjukkan kesatuan kaidah di dalam memperlakukan kedua jenis manusia, laki-laki dan wanita, sebagaimana ia juga merupakan nash yang sharih (jelas) di dalam 
mensyaratkan iman untuk dapat atas, diantaranya: (Quthb, 2001, jilid diterimanya suatu amalan. Tidak ada nilainya disisi Allah suatu amalan yang tidak bersumber dari iman dan tidak diiringi dengan iman. Ini adalah sesuatu yang alami dan logis, karena iman kepada Allah lah yang XIV:211): (a) Baik laki-laki maupun perempuan keduanya sama dalam kaidah amal dan balasan, sama dalam hubungannya dengan Allah dan ganjaran keduanya di sisi Nya, (b) Amal salih itu memiliki kaidah orisinil menjadikan amalan yang shaleh keluar dari pandangan dan niat tertentu, sebagaimana iman juga menjadikan amal shaleh sebagai gerakan alami dan terbiasa, bukan karena mengikuti keinginan pribadi, dan bukan sebagai lintasan pikiran yang tidak punya pijakan (Quth, 2001, Jilid V:83).

Begitu juga dalam surat An Nahl: 97:

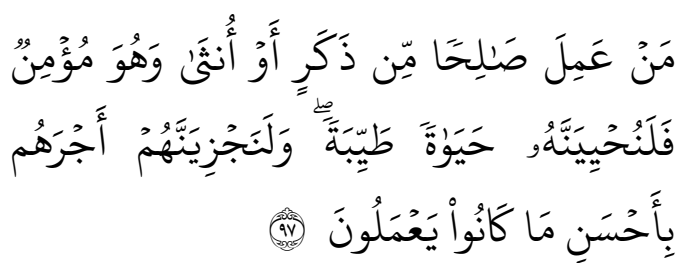
tersendiri yang dipusatkan kepada Allah SWT, (c) Balasan amal salih yang dilakukan dengan landasan keimanan adalah hayatan thayyiban (penghidupan yang baik) di dunia, dan (d) Penghidupan yang baik di dunia tidak akan mengurangi pahala yang mulia di akhirat.

\section{Tugas dan Fungsi Istri Salihah}

Dilihat dari tugas dan fungsi istri salihah dalam perspektif al-Quran adalah sebagai berikut:

Pertama: Istri yang patuh terhadap Barangsiapa yang mengerjakan amal saleh, baik laki-laki maupun perempuan dalam Keadaan beriman, Maka Sesungguhnya akan Kami berikan kepadanya kehidupan yang baik dan Sesungguhnya akan Kami beri Balasan kepada mereka dengan pahala yang lebih baik dari apa yang telah mereka kerjakan.

Dalam kitab Tafsir Fi Zhilalil Quran karangan Sayyid Quthb, beliau menjelaskan bahwa ada beberapa kaidah yang bisa di ambil dari ayat di kepemimpinan suami Q.S An Nisa': 34:

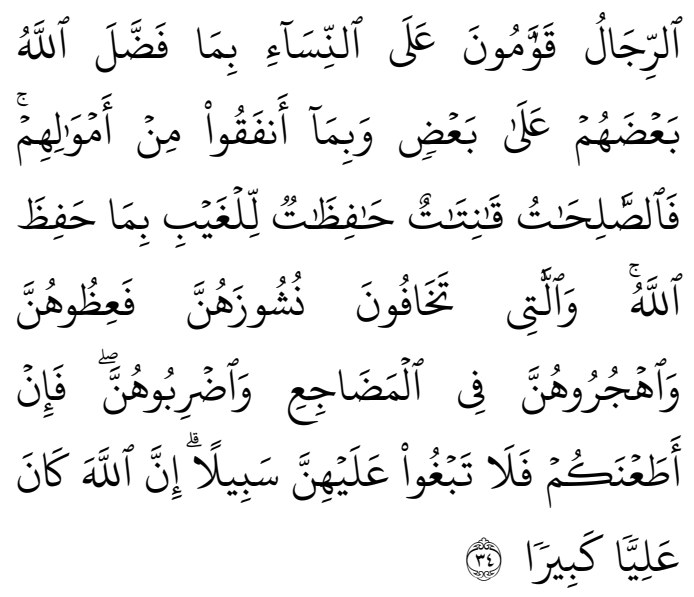


Kaum laki-laki itu adalah pemimpin bagi kaum wanita, oleh karena Allah telah melebihkan sebahagian mereka (laki-laki) atas sebahagian yang lain (wanita), dan karena mereka (laki-laki) telah menafkahkan sebagian dari harta mereka. sebab itu Maka wanita yang saleh, ialah yang taat kepada Allah lagi memelihara diri ketika suaminya tidak ada, oleh karena Allah telah memelihara (mereka). wanita-wanita yang kamu khawatirkan nusyuznya, Maka nasehatilah mereka dan pisahkanlah mereka di tempat tidur mereka, dan pukullah mereka. kemudian jika mereka mentaatimu, Maka janganlah kamu mencari-cari jalan untuk menyusahkannya. Sesungguhnya Allah Maha Tinggi lagi Maha besar.

Dalam Tafsir Al-Misbah, Quraish Shihab menjelaskan bahwa surat an Nisa' ayat 34 tersebut lebih cenderung menggambarkan kehidupan keluarga yang mengatur pembagian tugas dan tanggungjawab sesuai dengan peran dan fungsinya. Kata ar rijal dalam ayat tersebut menurut Muhammad Thahir Ibn Asyur, sebagaimana dikutip oleh Quraish Shihab tidak digunakan oleh bahasa Arab bahkan dalam al-Quran dalam arti suami.

Penafsiran tersebut menunjukkan suatu sikap progresif yang menempatkan perempuan sebagai mitra bagi laki-laki. Perempuan bukanlah sub ordinat dari kaum laki-laki, tetapi keduanya saling mengisi, keduanya diberikan kelebihan masing-masing agar dapat saling mengisi dan bertanggungjawab dengan tugas dan kewajiban yang diembannya (Shihab, 2000, vol 2:402-412).

Kedua: Memelihara diri dan melaksanakan kewajiban (Q.S Al Ahzab: 33:

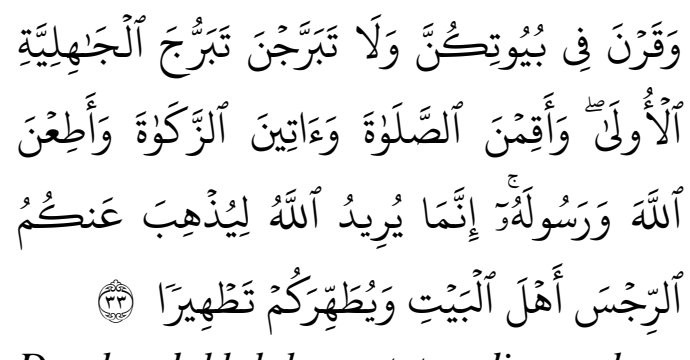

Dan hendaklah kamu tetap di rumahmu dan janganlah kamu berhias dan bertingkah laku seperti orang-orang Jahiliyah yang dahulu dan dirikanlah shalat, tunaikanlah zakat dan taatilah Allah dan Rasul-Nya. Sesungguhnya Allah bermaksud hendak menghilangkan dosa dari kamu, Hai ahlul bait dan membersihkan kamu sebersih-bersihnya.

Dalam kitab Tafsir An-Nur Hasbi Ash Shiddieqy menjelaskan bahwa, "Berdiamlah kamu di rumah-rumahmu dan janganlah menampakkan hiasanmu seperti keadaan perempuanperempuan jahiliah dahulu..." Dua pernyataan tersebut memberikan pengertian bahwa isteri-isteri Nabi tidak dibenarkan keluar dari rumah untuk memamerkan hiasan-hiasannya. Mereka diperbolehkan keluar, hanya apabila ada keperluan dan apabila 
mereka keluar rumah berlaku Ash Shiddieqy menjelaskan bahwa, sederhana, serta menghindari segala Allah membuat tamsilan untuk orangsesuatu yang menimbulkan prasangka orang beriman. Contoh yang ekstrem buruk dari orang-orang yang adalah Asiah istri Fir'aun, seorang memandangnya (Ash Shiddieqy, 2011, perempuan yang beriman dan salihah. Jilid 22:489-490).

Disamping memelihara diri dari Suami yang kafir dan hubungannya dengan orang-orang kafir ternyata tidak segala hal yang menimbulkan prasangka buruk, isteri-isteri Nabi di perintahkan untuk mendirikan shalat, memberikan zakat, serta menaati Allah dan Rasul Nya. Allah hanya mengkhususkan dua ibadat dalam ayat ini, karena shalat dan zakat sangat besar pengaruhnya untuk menyucikan harta dan jiwa (Ash Shiddieqy, 2011, Jilid 22:489-490).

Ketiga: Istri salihah yang mampu meneladani figur-figur istri shalihah dalam al-Quran Q.S At Tahrim: 11:

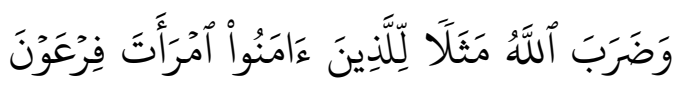

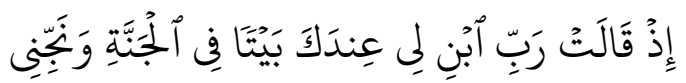

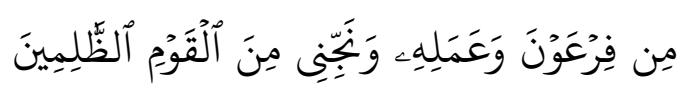

Dan Allah membuat isteri Fir'aun perumpamaan bagi orang-orang yang beriman, ketika ia berkata: "Ya Rabbku, bangunkanlah untukku sebuah rumah di sisi-Mu dalam firdaus, dan selamatkanlah aku dari Fir'aun dan perbuatannya, dan selamatkanlah aku dari kaum yang zhalim.

Dalam kitab Tafsir An-Nur, Hasbi memberi suatu kemudharatan atas keimanannya. Dia tetap beriman dan beramal saleh, dia selalu berdoa kepada Allah semoga Allah menjadikan dirinya tetap sebagai orang yang dekat dengan rahmat Allah (Ash Shiddieqy, 2011, 28:376).

Sebagaimana juga terdapat dalam surat Al Ahzab ayat 32:

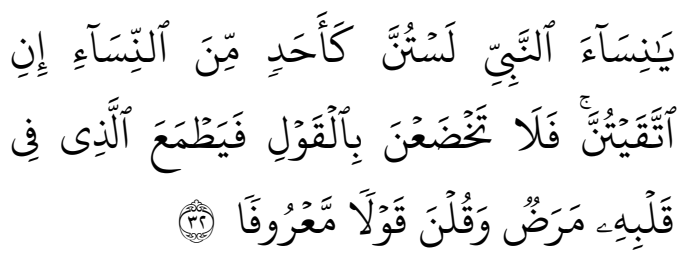

Hai isteri-isteri Nabi, kamu sekalian tidaklah seperti wanita yang lain, jika kamu bertakwa. Maka janganlah kamu tunduk dalam berbicara sehingga berkeinginanlah orang yang ada penyakit dalam hatinya dan ucapkanlah Perkataan yang baik,

Dalam kitab Tafsir Al-Misbah, Quraish Shihab menjelaskan bahwa kata takhda'na terambil dari kata $k h u d u$ ' yang pada mulanya berarti tunduk. Jika dikaitkan dengan ucapan, yang dimaksud adalah merendahkan suara. Wanita pada kodratnya memiliki 
suara lemah lembut. Atas dasar itu, terhadap apa yang diturunkan Allah larangan di sini harus dipahami dalam kepada Nabi Muhammad SAW, arti membuat-buat suara lebih lembut dengan tolak ukur: Pertama: Dilihat melebihi kodrat dan kebiasaan dari ciri seorang istri sebagai berbicara. Cara bicara yang perempuan salihah adalah sebagai menampakkan kemanjaan kepada berikut: (a) Mampu menahan lawan bicara yang dapat menimbulkan pandangan, (b) Menutup aurat, (c) hal-hal yang dilarang agama. Larangan Menjaga kehormatan diri, dan (d) ini berlaku kepada yang bukan Memiliki ketaatan secara utuh (kaffah) mahram, adapun berbicara dihadapan kepada Allah. Kedua: Dilihat dari suami pada dasarnya tidak terlarang tugas dan fungsi istri salihah dalam (Shihab, 2002, vol 11:463).

perspektif al-Quran adalah sebagai Sedangkan kata ma'rufan berikut: (a) Istri yang patuh terhadap dipahami dalam arti yang dikenal oleh kepemimpinan suami, (b) Memelihara kebiasaan masyarakat. Perintah mengucapkan yang ma'ruf, mencakup cara pengucapan, kalimat-kalimat yang diucapkan, serta gaya pembicaraan. Dengan demikian, ini menuntut suara yang wajar, gerak gerik yang sopan, dan kalimat-kalimat yang diucapkan baik, benar dan sesuai sasaran, tidak menyinggung perasaan atau mengunndang rangsangan (Shihab, 2002, vol 11:464).

diri dan melaksanakan kewajiban, dan (c) Mampu meneladani figur-figur istri shalihah dalam al-Quran.

\section{REFERENSI}

Armanto,

Juni. 2019.

https://indopos.co.id/read/2019/ 05/04/174066/istri-gugat-. 04 Mei $2019(19: 45)$

Hadhiri, C.SP. 1993. Klasifikasi Kandungan Al quran, Jakarta: Gema Insani Press

\section{KESIMPULAN}

Mulyadi, E. 2010. Membina Rumah

Hasil dari penelitian ini dapat disimpulkan bahwa, istri salihah dalam perspektif al-Quran yaitu istri yang beriman kepada Allah, taat, serta patuh Tangga yang Sakinah, Mawaddah, Warrahmah, Jakarta: Gramedia Pustaka Utama Shihab, M.Q. 2012. 
Tafsir al Lubab, Makna,

Tujuan, dan Pelajaran dari

Surat-Surat al Quran,

Tangerang: Lentera Hati

Hasbi, M.S. 2011. Tafsir An Nur, Cet-

1, Jakarta: Cakrawala

Publishing

Quthb, Sayyid. 2000. Tafsir Fi Zhilalil

Quran, Jakarta: Gema Insani 